\title{
REALISMO E NATURALISMO EM PORTUGAL: DEFINIR, CONTEXTUALIZAR, EXEMPLIFICAR
}

\author{
Lucia Maria Moutinho Ribeiro \\ Universidade Federal do Rio de Janeiro
}

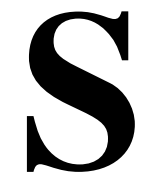

ejam prosadores como Camilo Castelo Branco, Eça de Queirós e Abel Botelho, sejam poetas como Cesário Verde e ... Antônio Nobre, identifiquemos procedimentos realistas (ou naturalistas) em algumas páginas de suas obras. Apesar da abrangência do título, a seleção dos autores se deve a motivos nem sempre óbvios. Eça de Queirós é tido como o ficcionista canônico de finais do século XIX em Portugal. Abel Botelho figura entre os inúmeros naturalistas propriamente ditos a cuja obra tivemos acesso. Camilo Castelo Branco percorre do romantismo ao realismo. A história da literatura geralmente classifica a poesia de Cesário Verde como realista. E a produção de Eça de Queirós e a de Antônio Nobre se viram limitadas pela morte de um e outro no mesmo ano, o ano de 1900. Ainda que a formação do segundo não fosse nem proudhoniana nem positivista nem realista, teria o poeta do Só respirado essa atmosfera, vazando-a em seus poemas. Vejamos pois se são pertinentes essas afirmações.

Argumentam os teorizadores que sempre houve realismo em arte como busca humana e instintiva da verdade desde o livro mais místico como a Bíblia, desde gregos e romanos que criaram deuses com feição humana; em meio às lendas da Ilíada e da Odisséia convivem as descrições mais precisas; Aristófanes sofrera a mesma hostilidade que Zola por ter ultrajado os costumes. ${ }^{1}$ Acontece que

${ }^{1}$ COGNY, 1963. p.16-17. 
os realistas do século XIX não só puseram em prática o cânone realista como também o sistematizaram, o teorizaram, o verbalizaram, tinham consciência do instrumento retórico que usavam como reação ao excesso de subjetivismo romântico.

Tentemos distinguir realismo de naturalismo. Um manual da coleção francesa "Que sais-je?" idealizada por Jean-Paul Sartre inclui Balzac, Stendhal, Flaubert e os Goncourt na fase de "gestação do naturalismo" e considera como naturalistas propriamente ditos os autores do grupo de Médan, assim chamados porque se reuniam em Paris em torno de Zola, que havia adquirido uma casa naquela cidadezinha. Eram eles Huysmans, Guy de Maupassant, Léon Hennique, Henry Céard e Paul Alexis. ${ }^{2}$ A menção a franceses se deve ao fato de ser a França "fonte suprema do Naturalismo", 3 apesar de a obra dos três últimos constituir "raridades em qualquer biblioteca" (por isso mesmo é que a sua leitura desperta curiosidade).

Fidelino de Figueiredo enfeixa os nomes de João de Deus, Antero de Quental, Teófilo Braga, Guerra Junqueiro, Cesário Verde, Gomes Leal, Eça de Queirós, Teixeira de Queirós, Júlio Lourenço Pinto, Abel Botelho, Oliveira Martins, Fialho de Almeida, Trindade Coelho, Wenceslau de Moraes e outros sob o rótulo História da literatura realista, em que distingue dois tipos de realismo. A saber: o "realismo arte pela arte [...] sem preocupações sociais, nem preconceitos morais, [...] desinteressad[o] de qualquer fim útil" e mais formal do que o "realismo utilitário, de tese, de intenção moral e propósitos reformadores, tendo em vista o aperfeiçoamento da humanidade", cujos fundamentos teóricos segundo ele são respectivamente o "materialismo socialista" e o positivismo proudhoniano. Afirma ainda que:

${ }^{2}$ COGNY, 1963. p.35-101.

${ }^{3}$ FURST, SKRINE, [1975]. p.42.

${ }^{4}$ FURST, SKRINE, [1975]. p.44. 
... entre estas duas interpretações do realismo, havia pontos de contato. Ambas repudiavam a ficção imaginosa [...]; ambas exigiam a mais rigorosa imparcialidade. E como conseguir esse fito? Não inventando, só registando a vida comum, quotidiana, com um grande amor do pormenor, convivendo em todos os meios, inquirindo e fazendo reportagem, pondo em obra documentos. ${ }^{5}$

Adiante acresce a classificação de Silva Pinto que dividia:

... escritores realistas em dois grupos, fisiologistas e psicologistas, segundo neles predominava a observação e descrição exteriores ou interiores, e considerava Eça de Queirós um eminente espírito artístico, que conciliava as duas orientações extremas num ecletismo sensato, [...] conducente à verdade. ${ }^{6}$

É Machado de Assis quem, a propósito dos célebres e arrasadores comentários a O crime do Padre Amaro e O primo Basílio para a revista $O$ Cruzeiro de abril de 1878 , primorosamente sintetiza os dois movimentos limítrofes na seguinte definição: "a nova poética /.../ só chegará à perfeição no dia em que nos disser o número exato dos fios de que se compõe um lenço de cambraia ou um esfregão de cozinha". ' A imagem do esfregão de cozinha, engordurado, encardido, grosseiro, está para o naturalismo com toda a carga negativa que imprime ao retrato do homem e da sociedade, assim como a do lenço de cambraia está para o realismo que se pretende menos parcial do que o naturalismo. E a imagem dos fios de que se tecem aqueles tecidos - equivalentes a narrativa, texto -, está para o esforço incomensurável dos narradores realista e naturalista de descrever a realidade com verossimilhança. Com isso ironiza Machado a desimportância do excesso de detalhismo da prosa eciana, porque esse recurso, ademais, será insuficiente para dar conta da verdade, pois a distância entre ficção e vida real é imensa.

\footnotetext{
${ }^{5}$ FIGUEIREDO, 1924. p.13-14 (nas citações dessa obra reservamo-nos o direito de atualizar a ortografia).

${ }^{6}$ FIGUEIREDO, 1924. p.20.

${ }^{7}$ ASSIS, 1960. p.157, v.29.
} 
Eça de Queirós tão irônico quanto o mestre brasileiro, porém mais discursivo, num prefácio projetado para a segunda edição de O crime do padre Amaro, recolhido postumamente no volume Cartas inéditas de Fradique Mendes e mais páginas esquecidas, sob o título "Crítica e polémica - idealismo e realismo", se o tivesse publicado teria respondido àquelas críticas assim: ${ }^{8}$

Outrora uma novela romântica, em lugar de estudar o homem, inventava-o. Hoje, o romance estuda-o na sua realidade social. Outrora no drama, no romance, concebia-se o jogo das paixões $a$ priori, hoje analisa-se a posteriori, por processos tão exatos como os da própria fisiologia. Desde que se descobriu que a lei que rege os corpos brutos é a mesma que rege os seres vivos, que a constituição intrínseca duma pedra obedeceu às mesmas leis que a constituição do espírito duma donzela, que há no mundo uma fenomenologia única, que a lei que rege o movimento dos mundos não difere da lei que rege as paixões humanas, o romance, em lugar de imaginar, tinha de simplesmente observar. /.../ A arte tornou-se o estudo dos fenômenos vivos e não a idealização das imaginações inatas...?

Eis uma definição de romance experimental como aquele que disseca o comportamento humano em sociedade assim como o médico ao se debruçar sobre um corpo. O médico, assinala o mestre Fidelino de Figueiredo, passa a ser figura quase obrigatória nos romances dessa fase: ${ }^{10}$ Carlos Eduardo da Maia, Julião Zuzarte, Charles Bovary, sem esquecer os boticários Eusébio Macário e seu filho José Fístula (não por acaso fístula quer dizer lesão e em sentido figurado sujeito de mau caráter).

Os dizeres de Eça de Queirós acima demonstram ainda como a arte se submete à ciência, deslumbrada que está com os princípios naturais detectados então. E o recurso retórico que acharam romancistas realistas e naturalistas para fundamentar teoricamente o enfoque científico de suas análises foi, pois, a descrição minuciosa ("processos

\footnotetext{
${ }^{8}$ REIS, 1984. p.17.

${ }^{9}$ QUEIRÓS, 1966. v.III, p.914.

${ }^{10}$ FIGUEIREDO, 1924. p.202.
} 
tão exatos" em Eça e "amor do pormenor" segundo Fidelino) para tornar o texto tão cientificamente objetivo e rigoroso quanto o exame de um protozoário ao microscópio. Ao falar em "lei" denota o autor filiar-se ao determinismo, a par de parecer machista e sexista por associar "uma pedra" ao "espírito de uma donzela". E por que não ao de um homem ou de uma senhora? Deixou de ser imparcial e "científico" por isso e deixou transparecer subjetividade ao selecionar aqueles termos de comparação, pois a ironia e o riso não escapam de uma visão subjetiva. O "observar" do enfoque realista ao substituir o "imaginar" do romântico sinaliza para o primado da onisciência da narrativa como instrumento mais eficaz para o "estudo" das "paixões humanas" e "dos fenômenos vivos", cultivada com mestria nos três grandes romances da chamada segunda fase da sua ficção: O crime do padre Amaro, Oprimo Basílio e Os Maias.

Induzido talvez pela crítica acerba do autor de Dom Casmurro, que, além do mais, julgou O crime do padre Amaro plágio de La faute de l'abbé Mouret de Zola, ambos publicados em 1875, Eça reformou o texto pela terceira vez em 1880. A sexualidade que pulsava nas "reuniões de saias e batinas" lideradas pela "padraria" (segundo o noivo da heroína João Eduardo) é que teria provocado a repulsa do mestre brasileiro. ${ }^{11}$

Relevemos a importância literária dos fatos da vida de um autor. Para João Gaspar Simões, a origem obscura do romancista português o levou a retratar amores proibidos, adulterinos, incestuosos, decorrentes da carência da mãe. O pai escondeu o nascimento ilegítimo do filho para não afetar a sua carreira de magistrado e mesmo tendo casado com a mãe do pequeno José Maria de Eça de Queirós, quando este contava quatro anos, e registrado os filhos nascidos da relação oficial, o criador de A ilustre casa de Ramires permaneceu afastado do seio familiar até os vinte e um anos. Depois de formado em Coimbra veio a conviver com os seus e só aos quarenta anos pôde regularizar seus papéis quando resolveu casar. Entretanto,

${ }^{11}$ CALHEIROS, 1996. p.195. 
rompeu com qualquer estigma que o pudesse marginalizar profissional ou socialmente. Muito pelo contrário, o sucesso e a imortalidade da sua obra contradisseram aquelas leis deterministas que ele mesmo aplicou na sua produção. Carlos Eduardo da Maia, protagonista de Os Maias, criado pelo avô (como Eça) e projetado para ser o fruto de uma educação vigorosa, não vinga. Tanto quanto o pai Pedro e as heroínas românticas Amélia e Luísa, Carlos resulta passivo, fantasioso e omisso, apesar de todos os esforços do avô para desviá-lo da herança genética. Diante da primeira decepção amorosa, se demite da ação, como médico não intervém a favor de outrem nem de si mesmo, prefere a "carreira" de diletante, porque tem posses e berço e não precisa lutar para sobreviver. Para Coimbra Martins a relação entre os irmãos Carlos e Maria Eduarda da Maia, fechados em si mesmos e indiferentes ao mundo que pulsa lá fora, nunca dará cria porque permanece tão estéril quanto a classe social a que pertencem. ${ }^{12}$ E o narrador de Os Maias, imparcial que é, não julga nada, limita-se a contar os fatos, tanto que a mãe dos jovens amantes consangüíneos, Maria Monforte, pela origem simples ("alguns amigos de Pedro [...] riam daquela obstinação de pai gótico, amuado na província, porque sua nora não tivera avós mortos em Aljubarrota!"13), entre outros motivos, não consegue conviver com a aristocrática família Maia. O bilhete que deixa para a filha esclarecendo o passado e desencadeando a catástrofe denota o estilo correto, objetivo e direto de alguém que não é nenhum literato mas sabe se expressar muito bem:

Como a Maria teve a pequena e anda muito fraca, e eu também não me sinto nada boa com umas pontadas, parece-me prudente, para o que possa vir a suceder, fazer aqui uma declaração que te pertence a ti, minha querida filha, e que só sabe o padre Talloux, (coadjuteur à Saint Roch) porque lho disse há dois anos, quando tive a pneumonia. Eéo seguinte: Declaro que minha filha Maria Eduarda, que costuma

12 Apud BERRINI, 1985. p.59.

${ }^{13}$ QUEIRÓS, 1966. v.II, p.29. 
assinar Maria Calzaski, por supor ser esse o nome de seu pai, é portuguesa e filha de meu marido Pedro da Maia, de quem me separei voluntariamente, trazendo-a comigo para Viena, depois para Paris, e que agora vive em companhia de Patrick Mac Gren, em Fontainebleau, com quem vai casar. Eo pai de meu marido era meu sogro Afonso da Maia, viúvo, que vivia em Benfica e também em Santa Olávia, ao pé do rio Douro. O que tudo se pode verificar em Lisboa, pois devem lá estar os papéis; e os meus erros, de que vejo agora as conseqüências, não devem impedir que tu, minha querida filha, tenhas a posição e fortuna que te pertencem. E por isso aqui declaro tudo isto que assino, no caso que o não possa fazer diante dum tabelião, o que tenciono logo que esteja melhor. E de tudo, se eu vier a morrer, o que Deus não permita, peço perdão a minha filha. E assino com o meu nome de casada-Maria Monforte da Maia. ${ }^{14}$

Bem distinta da dicção depurada de Eça de Queirós, mas carregada de afeto maternal, a mensagem vem confirmar a imparcialidade e a onisciência do narrador realista (talvez perdidas por todo o sempre para quem gosta de devorar romances lineares, bem contados, com uma história bem circunscrita, com suspense, peripécias, personagens variados, porque a narrativa dos séculos XX e XXI o despreza). A notícia da fatalidade indiciada desde as primeiras páginas pela casa do Ramalhete - cujos muros segundo Afonso viram "tantos desgostos domésticos", ao que responde o procurador Vilaça, "acontecia a todos os muros"15 -, é trazida por um mensageiro tão extemporâneo que mais parece um demônio (lembre-se a força trágica do romance estudada por Carlos Reis): "Pararam à porta do Teatro da Trindade no momento em que, duma tipóia de praça, se apeava um sujeito de barbas de apóstolo, todo de luto, com um chapéu de largas abas recurvas à moda de 1830", ${ }^{16}$ "o chapéu recurvo, as barbas brancas do Sr. Guimarães". ${ }^{17}$

\footnotetext{
${ }^{14}$ QUEIRÓS, 1966. v.II p.440.

15 QUEIRÓS, 1966. v.II, p.8.

${ }^{16}$ QUEIRÓS, 1966. v.II, p.405.

${ }^{17}$ QUEIRÓS, 1966. v.II, p.424.
} 
Com o subtítulo "Episódios da vida romântica", o romance presta conta de reproduzir o cenário social e aristocrático do Portugal regenerador (lembre-se novamente a análise de Carlos Reis), com figurantes que representam a política, as finanças, o jornalismo sensacionalista e corrupto, a futilidade e o exibicionismo, a neutralidade diplomática e o esforço de seus membros parecerem tão civilizados e elegantes como os personagens que circulam em A procura do tempo perdido de Marcel Proust. São dois romances que bem merecem uma comparação através do enfoque do narrador, objetivo de um e subjetivo de outro.

A rubrica "Cenas da vida real" sobre o universo romanesco eciano enfeixaria a intenção de reproduzir a pseudo-estabilidade da Regeneração, termo que para Oliveira Martins designa o capitalismo do século XIX do Portugal liberal. Porém, dizem os críticos, nesse painel social não aflora a luta de classes. A não ser por um único personagem - Juliana, empregada doméstica de Luísa, protagonista de Oprimo Basílio, romance em que a visão das classes sociais não é idealizada nem maniqueísta. Juliana sabe que é explorada pelos patrões, se revolta contra isso, dizendo que até o quarto dos baús tem janela, enquanto o seu é abafado e infestado de bichos. Ao chantagear a patroa, dá uma virada na sua posição subalterna, mas é derrotada pela classe mais forte. Aí exibe o narrador realista mais uma vez domínio imparcial da técnica da onisciência narrativa, porque a "vilã" é vencida, sim, pela classe dominante, a grande vencedora de sempre, a classe do velho amigo, o aristocrata Sebastião, "o grande Sebastião, o Sebastiarrão, Sebastião tronco de árvore", ${ }^{18}$ encarado assim com essa ternura, não pelo narrador, mas sim pelo amigo Jorge. Se Juliana há-de reclamar da "piorrinha" é porque é forçoso e humano fazê-lo, a não ser que fosse conformada como Joana e não soubesse o que é injustiça. Por outro lado, o que quer mesmo é uma parte da herança dos patrões para vir a ocupar a mesma posição. Se o texto a encara com antipatia de antagonista e

${ }^{18}$ QUEIRÓS, 1966. v.I, p.892-893. 
vê maldade nas suas reações é porque esse é o enfoque dos personagens de classe média (bem como será o do leitor) que gravitam em torno do casal: "A boa escolha dos fâmulos é uma condição de paz no adultério", ${ }^{19}$ afirmava o mordaz Machado de Assis nos comentários já mencionados. Jean Genet na peça As criadas reproduz situação semelhante de inversão de valores na hierarquia social capitalista, em que vêm patrões a ocupar funções de empregados e vice-versa.

Que outro romance haveria de retratar uma virgem cinqüentona e apaixonada como Dona Felicidade com cintura larga devido a problemas intestinais que lhe provocam gases? Ou pintar seu amado com uma careca tão luzidia e fálica como a do Conselheiro Acácio?

A pessoa do conselheiro viera de repente, um dia, pegar fogo àqueles desejos, sobrepostos como combustíveis antigos. Acácio tornara-se a sua mania: admirava a sua figura e a sua gravidade, arregalava grandes olhos para a sua eloqüência, achava-o numa "linda posição". O conselheiro era a sua ambição e o seu vício! Havia sobretudo nele uma beleza, cuja contemplação demorada a estonteava como um vinho forte: era a calva. Sempre tivera o gosto perverso de certas mulheres pela calva dos homens, e aquele apetite insatisfeito inflamara-se com a idade. Quando se punha a olhar para a calva do Conselheiro, larga, redonda, polida, brilhante às luzes, uma transpiração ansiosa humedecia-lhe as costas, os olhos dardejavam-lhe, tinha uma vontade absurda, ávida, de lhe deitar as mãos, palpá-la, sentir-lhe as formas, amassá-la, penetrar-se dela! Mas disfarçava [...]. Ia para casa rezar [...]; mas apenas as orações findavam, começava o temperamento a latejar. ${ }^{20}$

Em Portugal, pode-se considerar Eça de Queirós tão naturalista quanto Abel Botelho por conta dos temas picantes de que tratam e que tanto chocaram o Bruxo do Cosme Velho, apesar da elegância da prosa eciana que a do segundo, mais factual, não tem, parecendo por isso mais naturalista do que aquela. Tomemos como exemplo

\footnotetext{
19 ASSIS, 1960. p.163.

${ }^{20}$ QUEIRÓS, 1966. v.I, p.886.
} 
O livro de Alda, de 1895, segundo volume da série Patologia social, constituída de cinco romances com o intuito de realizar o programa naturalista. Trata-se de um bildungsroman feminino (com enredo semelhante a Nome de guerra de 1938 de Almada Negreiros). Contado pelo protagonista masculino, Mário, estudante de medicina em Lisboa, sob a forma de diário retrospectivo datado de 15 de fevereiro a 23 de março de 1893, relata o seu envolvimento sexual com uma prostituta, Alda, cujo destino, pela voz daquele, vimos a conhecer de cabo a rabo. A narrativa nos diz que naquela época a finalidade da mulher era ou o casamento ou a prostituição, ou seja, a dependência do homem. Enquanto Branca, noiva do narrador, é figura plana, a típica virgem inocente e rica que não suporta frustração e morre de desgosto, Alda sobrevive a todas as adversidades desde o parto que provocou a morte da mãe. Bastarda, órfã, menor abandonada, é acolhida por um tio, o qual "apontavam-no as mães às filhas; era o lume e a esperança dos orgasmos sensuaes das solteironas"; ${ }^{21}$ entrega a sobrinha a uma babá e depois a toma como mulher aos doze anos. Alda fugirá dele assim como de mais uns três amantes. Batendo de déu em déu, tenta o emprego doméstico até prostituir-se e conhecer o jovem Mário num baile de carnaval. A graça e a leveza irresistível de Alda lhe advieram do convívio com a natureza e da liberdade de que desfrutou durante a infância no campo. O texto descreve cenas de sexo explícito: “- Se isto durasse muito... a gente endoidecia! - murmurou ela, passado um instante, devagar, numa expiração de alívio alteando o tórax e cerrando os olhos", ${ }^{22}$ tanto quanto os romances de Eça de Queirós citados. A naturalidade de tais descrições motivou censura da crítica ${ }^{23}$ (Machado de Assis não foi o único), principalmente porque focalizam homem e mulher com os mesmos instintos: "Toda a beleza de Maria, todo o requinte de Carlos, desapareciam. Ficavam só dois

${ }^{21}$ BOTELHO, 1927. p.167.

22 BOTELHO, 1927. p.239.

${ }^{23}$ FIGUEIREDO, 1924. p.21-24. 
animais, nascidos do mesmo ventre, juntando-se a um canto como cães, sob o impulso bruto do cio". ${ }^{24}$

Abel Botelho desenvolve também conforme preceito da escola o gosto pelo detalhe que, em vez de supérfluo, lhe confere não só cor local, mas principalmente dinamismo. Está-se no tempo da difusão do daguerreótipo e no ano da invenção do cinema, o mesmo da publicação de O livro de Alda, logo a literatura mais não faz do que se apropriar dos recursos cinéticos daqueles:

Foi assim que, logo à boca da noite, eu apressado rodei té ao Arco da Bandeira, e ao longo dessa funda valeira, bafienta e lôbrega, curei de atinar com a porta provável ao funambulesco e bocagiano colégio da D. Manuela. [...]

No princípio não dei com o dono da imunda locanda. Varria a um canto da loja. Era um tamanhão dum paquiderme, todo vestido de fustão azul, grande, maciço, obeso, rosto opado de cardíaco, sobre a russa grenha uma boina de seda, reluzente de surrampa, [...] puxava agora acima as calças distensas e caídas das prolongadas genuflexões, e sobre elas e a blusa reatava depois a corda a que ele atribuía simultaneamente funções de suspensório e de cinto.

Eu queria-me aproximar, interrogá-lo [...]. Mas a cenha do marmanjão acobardou-me... Já me contentaria então em me aproximar da porta, mudamente interrogar aquelas pedras que ela decerto havia pisado tanta vez! [...]

Aqui, atravessa claudicando a rua um esmadrigado velho, alcachinado e trôpego, andrajoso também, vistoso boné marcial, uma pala num olho. O guarda-portão do club fronteiro. Adiantouse, subiu o degrau e espalmando diante do boné a mão direita, saudou:

- Guarde-o Deus, sor Matias! ${ }^{25}$

A citação é longa para não amputar a intenção de, como o olho da câmera de filmar em grande plano, abranger toda a cena sem seleção, desde a busca do protagonista, com a vantagem de revelar o seu íntimo - que só a linguagem tem - até "o dono da

${ }^{24}$ QUEIRÓS, 1966. v.II, p.431.

${ }^{25}$ BOTELHO, 1924. p.221-222. 
imunda locanda" e a chegada do porteiro da casa em frente, assim compondo o cenário. Se a reprodução fosse pictórica, fotográfica ou cinematográfica, os atos apareceriam quase que simultaneamente porquanto a sucessão deles decorre por diferença de segundos. Como a linguagem é linear, os recursos retóricos do narrador realista, carentes de tecnologia, cores e movimento em relação àqueles, ficam a dever. Por outro lado, ganham por revelar a ansiedade e a timidez do personagem, percebidas pelo emprego de vocabulário de conotação negativa, até porque o lugar é lúgubre e digno de meter medo mesmo tanto quanto o dono dele, chamado pelo narrador e protagonista que obviamente diz eu de "paquiderme", "marmanjão", "mastodonte" e "monolito"26 no mesmo trecho. Dificilmente a câmera de filmar poderia dar conta do temor do estudante a não ser por uma voz em off que é um recurso mais dramático do que narrativo. De fato a descrição minuciosa das figuras acima seria dispensável se não precisasse a narrativa como que fotografar o quadro. Por isso diz-se que o estilo de Abel Botelho é enxundioso e envelheceu, porém marca a voga de um movimento que perdurou até a segunda década do século XX - as séries de contos de Teixeira de Queirós Comédia burguesa e Comédia do campo datam respectivamente de 1879-1919 e de 1876-1913.

Parecem os personagens enumerados: Amélia, Luísa, Pedro, Carlos, Maria Monforte, Maria Eduarda, Juliana, Mário, Alda, Branca, confirmar a tese defendida por Spencer sobre a sobrevivência do mais forte, mas sem privilégio de classe social.

Agora, se o triângulo amoroso de Amor de perdição formado por Mariana, Teresa e Simão sucumbe não foi devido ao mesmo motivo. Muito pelo contrário. Considerado ultra-romântico, este romance, entretanto, traz páginas realistas e de discussão sobre o próprio realismo (cf. capítulo XIX) ou não veríamos seu herói amantíssimo envolvido com problemas de falta de dinheiro (cf. capítulo VIII).

${ }^{26}$ BOTELHO, 1924. p.222. 
Em Eusébio Macário (1879) e A corja (1880) subintitulados "História natural e social de uma família no tempo dos Cabrais", já que o segundo é continuação do primeiro, a produção camiliana emula intencionalmente o naturalismo português e o de Zola, como afirma o autor em "Nota preliminar" e no "Prefácio da segunda edição" a essas obras. Para tanto, recorrem aos mesmos processos apontados anteriormente, mas já aí com intenção paródica, como a descrição minuciosa de um relógio de parede que abre o primeiro romance da série. Em seguida a enumeração exaustiva das mezinhas manipuladas por José Fístula, que se torna farmacêutico como o pai Eusébio, demonstra o quanto Portugal estava longe do progresso científico que a Geração de 70 queria atingir. Contam desvios de comportamento, intrigas, misérias humanas, amores ilícitos, adulterinos ou sustentados por interesses materiais ou por atração meramente física como a do abade Justino por Felícia, sem vestígio porém de sentimento de culpa e de remorso como acontecera com Amélia e Luísa. Há flashes de carícias sexuais:

Uma vez o José, para se exprimir sensivelmente, apanhou de surpresa a Felícia, e deu-lhe alguns beijos famintos, mordentes, sorvidos, cáusticos como ventosas, na cara, no pescoço, com a paixão quente e descomposta de um noivo moderno, como os de Teixeira de Queirós. ${ }^{27}$

O narrador é onisciente, sim, mas às vezes também comenta os artifícios narrativos, o que o narrador das obras ecianas de ficção mencionadas aqui para preservar imparcialidade jamais faria. Vejamse os exemplos acima (de Eusébio Macário) e abaixo (de A corja):

Segundo o convencionalismo dos processos modernos, estas percepções deixam-se a quem lê; mas desta vez, sem exemplo, ajuda-se o leitor a perceber, - sim, isto não é a subjetividade, a interpretação imposta: é simplesmente um modo de ver o tecido grosseiro dos lindos gobelins, examinados ao invés. ${ }^{28}$

${ }^{27}$ BRANCO, 1960. v.II, p.660.

${ }^{28}$ BRANCO, 1960. v.II, p.705. 
Ademais o falar, o escrever nortenho de Camilo dista bastante da prosa urbana, enxuta e "moderna" (termo emprestado da citação de Eusébio Macário a propósito do "noivo moderno, como os de Teixeira de Queirós") de Eça de Queirós.

Contemporâneo destes, Cesário Verde mal foi reconhecido no seu tempo, porque ousou trazer para o gênero lírico a feiúra, "as flores do mal" da realidade social injusta, a cidade insalubre, o campo não idealizado, os desfavorecidos. Teófilo Braga ridicularizou o primeiro poema "Esplêndida" de 1874, dizendo que o poeta deveria ser "mais Cesário e menos Verde", isto é, mais autêntico e maduro, e não o incluiu no Parnaso português moderno que organizou. Entretanto, Cesário uniu-se a ele e a Ramalho Ortigão em manifestações republicanas e, como contribuição política sua para a comemoração do tricentenário de Camões, compôs "O sentimento dum ocidental" (e que contribuição política!... se não fosse também estética):

Num cuteleiro, de avental, ao torno

Um forjador maneja um malho, rubramente;

E de uma padaria exala-se inda quente,

Um cheiro salutar e honesto a pão no forno.

E eu que medito um livro que exacerbe

Quisera que o real e a análise mo dessem;

Casas de confecção e modas resplandecem;

Pelas vitrines olha um ratoneiro imberbe. ${ }^{29}$

O "ratoneiro imberbe", ladrão de pequenos furtos, o pivete ou trombadinha na linguagem brasileira, ao lado de vitrines luxuosas de casas de confecção e modas, denuncia o conflito latente da vida urbana e desenvolvida de então, bem longe dos pacíficos saraus descritos em Os Maias. E o poeta diante desse "real" conturbado quer dele a "análise" para o transpor poeticamente e dele fornecer uma visão muito sua num "livro que exacerbe", isto é, que traduza esse real tão detalhadamente e exageradamente que o retrato possa parecer mais veraz do que a própria realidade. Será esse o

${ }^{29}$ VERDE, 1995. p.120 (citações retiradas desta edição). 
fundamento da própria arte que esclarece, conscientiza e ensina quando a contemplamos, como queriam realistas e naturalistas.

Acontece que à medida que tentamos circunscrever um conceito literário e artístico (como propusemos desde o início) nos surpreendemos, pois o artista o supera. Sendo assim, verificamos que os recursos retóricos da poética de Cesário de fato pintam a realidade, mas com um viés cubista e expressionista, porque a deformam, a exacerbam, através de imagens que subvertem a geometria e o sentido das formas, conforme se vêem no poema Num bairro moderno frutas e legumes tomando forma feminina eroticamente sedutora: melancia se transforma em cabeça, repolhos em seios, azeitonas em cabelos, nabos em ossos, cachos de uvas em olhos, melão em ventre, ginja em sangue, tomate em coração, cenouras em dedos, através de uma prodigiosa sugestão plástica, visual, cromática, pictórica, impregnada de erotismo - "Vi nos legumes carnes tentadoras" (Num bairro moderno, p. 98) - e de perversão à medida que fala em ossos e traduz delírio - "que visão de artista!" (Num bairro moderno, p. 97).

Sublinhemos o léxico que define a arte poética verdiana:

a) "Milady, é perigoso contemplá-la," "com seus gestos de neve e de metal'; "O seu olhar [...] Como um florete fere agudamente [...]. E enfim prossiga [...] Sem sorrisos, dramática, cortante" (Deslumbramentos, p. 82-3);

b) "Ó gélida mulher, [...] Metálica visão [...], / Permita que eu lhe adule a distinção que fere [...]. E se uma vez me abrisse o colo transparente, / E me osculasse [...] Eu julgaria ouvir alguém, agudamente, / Nas trevas, a cortar pedaços de cortiça!" (Frígida, p. 85);

c) "Amo, insensatamente, os ácidos, os gumes/E os ângulos agudos" ( "Contrariedades", p. 93);

d) "Pinto quadros por letras, por sinais [...]. As ferramentas, os trabalhadores! [...] Os paralelogramos das adegas, [...] sem talento, /Faço um trabalbo técnico, violento, (Nós, p. 132-139); 
e) "Sei só desenho de compasso e esquadro" (De verão, p. 147).

Ao preferir linhas retas, geométricas e pontiagudas parece dizer o poeta: quero ferir a quem me ler, pois minhas imagens serão tão contundentes quanto ácidos, gumes, ângulos agudos, porque vão denunciar a dor da verdade, a maldade do mundo e impulsos humanos, de maneira objetiva, direta e elaborada. Cesário inaugura a abordagem de temas inauditos em poesia, ao revelar "não só aguda consciência da linguagem e do fazer do texto, mas também a da obra como mercadoria, subordinada às leis da competição e à do artista como produtor de mercadorias", ${ }^{30}$ ao registrar o trabalho e o trabalhador como motivos de expansão lírica e a satisfação erótica, tal como os prosadores realistas:

E eu que busco a moderna e fina arte, Sobre a umbrosa calçada sepulcral, Tive a rude intenção de violentar-te Imbecilmente, como um animal! (Noite fechada, p.152-154)

Embora o severo Teixeira de Pascoaes tenha afirmado algures que Antônio Nobre figura entre as "poetisas portuguesas", este também focaliza o amor não platônico pelo menos nas ocorrências:

Mulher e filhos! A Mulherzinha

Tão loira e alegre, Jesus! Jesus!

E, em nove meses, vê-la choquinha

Como uma pomba dar outra à luz.

(Canção da felicidade, ideal dum parisiense) $)^{31}$

Georges! Anda ver meu país de romarias

E procissões!

Olha essas moças, olha estas Marias!

Caramba! Dá-lhes beliscões!

Os corpos delas, vê! São ourivesarias,

30 ALMEIDA, 1988. p.76.

${ }^{31}$ NOBRE, 1976. p.52 (citações retiradas desta edição). 
Gula e luxúria de Manéis!

[...]

Vá! Georges, faze-te Manel! Viola ao peito,

Toca a bailar!

Dá-lhes beijos, aperta-as contra o peito.

Que hão de gostar! (Lusitânia no Bairro Latino, p. 36)

O Sóde Antônio Nobre atingiu popularidade considerável, apesar das inúmeras controvérsias surgidas na época de sua publicação em Paris pelo editor Léon Vanier, o mesmo dos simbolistas franceses Verlaine, Rimbaud e Mallarmé. Que prestígio teria alcançado por lá, graças a Deus, um jovem estudante português de 25 anos apenas? É bem verdade que as despesas correram por conta do autor, com uma tiragem restrita de 200 exemplares, dos quais reteve 100 para distribuir entre amigos e familiares. Causou tanta repercussão em Portugal que se formaram em torno do livro partidos de apoio poucos - e de rejeição - muitos. Inveja. O texto obedece a ordem gráfica tão rigorosa e bela, até mesmo o índice - a "Tábua" que o próprio criador desenhou ${ }^{32}$-, os títulos e subtítulos, que dão a dimensão do vir a público de uma obra conscientemente elaborada.

Em abril, mês da publicação, Novidades prontamente apresenta uma chacota em tom de zombaria: a paródia "Pó, sinfonia lírica para trombone". Pinheiro Chagas, em julho, no jornal O País, do Rio de Janeiro, o ataca violentamente, o que motiva respostas favoráveis de Silva Pinto, no jornal $A$ Voz Pública, em artigos intitulados "Ao correr do pelo". Além disso, houve insinuações do agressivo grupo da revista coimbrã Insubmissos, com o lema "De lança em riste", de Antônio Nobre ter plagiado o Guerra Junqueiro de Os simples, apelidando-o de "António Junqueiro da Guerra Nobre”. Em carta a Antônio Nobre, porém, o próprio Guerra Junqueiro põe fim às calúnias, provando ser o fato inverídico, pois a sua composição é de maio, logo um mês depois da vinda a público do Só, do qual muitos poemas datam de antes de 1892. A segunda

32 CASTILHO, 1950. p.307-309. 
edição surpreende o poeta em 1898 e não pára de se imprimir desde então (entre as várias casas editoras que o terão publicado a que usamos computa em 1976 a décima sétima edição). Conta-se que quando concluía o curso de direito em Paris esteve com o cônsul de Portugal Eça de Queirós que o recebeu friamente. ${ }^{33}$ A poética finissecular nobriana é, sim, neo-romântica, triste, lamurienta, egocêntrica, autocomiseradora, quimérica e autobiográfica. Nela se reconhecem passos da sua vida. O eu poético cita o nome de "António", o mesmo nome do autor que figura na capa do livro e que, por isso, passa a ser personagem de $3^{\text {a }}$. pessoa. Alude às pessoas com quem o poeta teria convivido: Carlota, Manuel, Georges, a noiva Purinha. Clama por Miss Charlote, professora de inglês e namorada durante veraneio na propriedade da família em Leça-a-Palmeira. Apropriando-se da tendência de sintetizar própria da língua inglesa, ela o chama de "Anto", apelido que alguns poemas incorporam. O poeta do Só evoca a Coimbra que o reprovou duas vezes. Cita preferências literárias, sobretudo Garrett e Shakespeare. Brinca com o jeito dândi de ser. Reporta as viagens. Todo esse narcisismo o leva então a exclamar: "Queixa-se o meu editor e todos que falo só de mim. Mas não sou eu o intérprete das dores do meu país?"33

O que aquelas paródias não relatam é o eco entre estrofes de Nós de Cesário Verde e de Lusitânia no Bairro Latino de Antônio Nobre que ilustram a máxima realista presente nos versos do primeiro - "Nós não vivemos só de coisas belas,/Nem tudo corre como num romance!" (Nós, p. 139). Este poema representa uma ode ao trabalhador braçal e à faina campesina, o plantio, a recolha, o armazenamento e a exportação das uvas, a propósito da doença fatal que vitimou os irmãos de Cesário e ele mesmo depois. Há uma oposição entre o lá da Europa do Norte "das frutas ácidas, tardias"

33 Cf. RIBEIRO, 1980. p.6-7.

${ }^{34}$ SERRÃO, [s.d.]. p.201. 
(Nós, p. 131) e o cá "das ricas primeurs da nossa terra" (Nós, p. 131) - entre a Inglaterra industrializada e o Portugal agrário:

Ó cidades fabris, industriais,

De nevoeiros, poeiradas de hulha,

Que pensais do país que vos atulha

Com a fruta que sai dos seus quintais? (Nós, p. 131)

Entretanto, nessa terra de fartura e beleza, "um de nós caiu, de súbito, doente./Uma tuberculose abria-lhe cavernas!" (Nós, 143).

Da mesma maneira, Lusitânia no Bairro Latino exalta o Portugal pitoresco do pastoreio de cabras, lendas, pescadores e romarias em detrimento da sofisticada França representada aí pelo amigo Georges. Enquanto o texto de Verde é mais parnasiano e pictórico, obedecendo a quadras rigorosamente rimadas e metrificadas em decassílabos, o de Nobre é mais livre, alternando métricas, rimas e estrofações variadas, pois já lá se vão oito anos entre a feitura de um e outro. Nós surgiu em Paris, Ilustração, a 5 de setembro de 1884 e Lusitânia é datado de Paris, 1891-1892. Impregnado de ternura, este também exalta o trabalhador: "Lavadeira que lavas o lençol", "Ó ceifeira que cegas cantando,/Ó moleiro das estradas", "Ó padeirinhas a amassar o pão,/Velhinhas na roca a fiar", "Pescadores a pescar" (p. 29), bem como contrasta fartura e miséria, que de fato a obra eciana desconheceu:

Clama um ceguinho:

"Não há maior desgraça nesta vida, que ser ceguinho!"

Outro moreno, mostra uma perna partida!

Mas fede tanto, coitadinho ...

Este, sem braços, diz "que os deixou na pedreira ..."

E esse, acolá, todo o corpinho numa chaga,

Labareda de cancros em fogueira,

Que o sol atiça e que a gangrena apaga,

Ó Georges, vê! Que excepcional cravina ...

Que lindos cravos para pôr na botoeira!

Tísicos! Doidos! Nus! Velhos a ler a sina! 
Etnas de carne! Jobes! Flores! Lázaros! Cristos! Mártires! Cães! Dálias de pus! Olhos-fechados! Reumáticos! Anões! Delíriums-trémens! Quistos! Monstros, fenómenos, aflitos, aleijados, Talvez lá dentro com perfeitos corações: Todos, à uma, mugem roucas ladainhas, Trágicos, uivam "uma esmolinha plas alminhas Das suas obrigações!"

Pelo nariz corre-lhes pus, gangrena, ranho!

E, coitadinhos! Fedem tanto: é de arrasar ...

Qu'é dos Pintores do meu país estranho, Onde estão eles que não vêm pintar? (p. 39)

O pintor ocuparia o lugar da onisciência narrativa que o gênero lírico obviamente não tem e as passagens comentadas dos poemas de Cesário Verde e Antônio Nobre fixam quadros de Portugal que não tinham se registrado em arte até então.

Não tivemos intenção aqui de esgotar o assunto que os limites deste ensaio não comportam, senão apenas a de apontar caminhos para uma pesquisa sobre realismo e naturalismo em Portugal de um ponto de vista comparatístico entre prosadores e poetas daquele momento, rejubilando-nos pelos dois centenários em tela.

\section{Referências Bibliográficas}

ASSIS, Machado de. Critica literária. Rio de Janeiro: Jackson, 1960. v.29.

BERQUÓ, Franca Alves et al. Homenagem a Antônio Nobre. Boletim do Sepesp, Rio de Janeiro, Faculdade de Letras, UFRJ, v.5, p.4990, nov. 1993.

BERRINI, Beatriz. O mundo de Eça de Queirós. Lisboa, São Paulo: Fundação Calouste Gulbenkian, Fundação Cultural BrasilPortugal, Bradesco Seguros, 1985.

BOTELHO, Abel. O livro de Alda. Patologia social. Porto: Lélo \& Irmão, 1927. v.4. 
BRANCO, Camilo Castelo. Obra seleta. Rio de Janeiro: Aguilar, 1960. $2 \mathrm{v}$.

CALHEIROS, Pedro. Machado, discípulo de Eça? In: XXVIII Congresso Brasileiro de Lingua e Literatura. Rio de Janeiro, 1996 /Anais.../. Rio de Janeiro: Sociedade Brasileira de Língua e Literatura, 1997. p.191-205.

CASTILHO, Guilherme de. António Nobre. Lisboa: Bertrand, 1950.

COGNY, Pierre. Le naturalisme. Paris: Presses Universitaires de France, 1963 [Collection Que sais-je?].

DICIONÁRIO DE LITERATURA. COELHO, Jacinto do Prado (Dir.). 4.ed. Porto: Figueirinhas, 1976. 3.v.

FIGUEIREDO, Fidelino de. História da literatura realista (19711900). 2.ed. Lisboa: Clássica, 1924.

FURST, Lilian, SKRINE, Peter. O naturalismo. Trad. Luís Pinguelo. Lisboa: Lysia, [1975].

JESUS, Maria Saraiva de. Alguns estereótipos sobre a mulher na segunda metade do século XIX. Veredas - Revista da Associação Internacional de Lusitanistas, Coimbra, Faculdade de Letras, n.1, p.149-163, dez. 1998.

NOBRE, António. Só. 17.ed. Porto: Tavares Martins, 1976.

QUEIRÓS, Eça de. Obras. Porto: Lello, 1966. 3 v.

REIS, Carlos. Introdução à leitura d'Os Maias. 4.ed. Coimbra: Almedina, 1984.

RIBEIRO, Lucia Maria Moutinho. O pacto autobiográfico no SÓ de Antônio Nobre. Rio de Janeiro: Faculdade de Letras, UFRJ, 1980. 108p. (Dissertação de Mestrado em Literatura Portuguesa)

SERRÃO, Joel. O tédio de António Nobre e a génese de O desejado. Temas oitocentistas. Lisboa, Portugália, n.2, p.189-915, [s.d.].

VERDE, Cesário. Cesário Verde: todos os poemas. SILVEIRA, Jorge Fernandes da (Org.). Rio de Janeiro: Sette Letras, 1995. 


\section{Resumo}

O artigo homenageia o centenário de Eça de Queirós e de Antônio Nobre inserindo-os no contexto finissecular e de cunho realista. A história da literatura considera o enfoque naturalista mais exagerado do que o realista, embora ambos se apropriem dos mesmos recursos retóricos como: dar primado à onisciência da narrativa, de que O crime do padre Amaro, O primo Basílio e Os Maias são exemplos cabais; descrever minuciosamente a realidade, como Abel Botelho nos romances da série Patologia social; focalizar a atividade sexual e denunciar a pobreza. Se a crítica reputa o excesso descritivo como enxúndia demonstra-se que o detalhismo cumpre uma funcionalidade ficcional, de que Camilo Castelo Branco também se apropriou no díptico Eusébio Macário e $A$ corja. Fulcro da ação nas narrativas abordadas, a sexualidade, que tanto chocou e atraiu o público, não deixa de figurar na poesia de Cesário Verde e de Antônio Nobre. Estes poetas, ademais, cantam a verdade do trabalho, do trabalhador, das classes populares e da miséria social, ausente nos três primeiros. Terá sido esse fator de modernidade que provocou a rejeição da poética cesarina e nobriana.

\section{Résumé}

L' article fait hommage au centenaire d'Eça de Queirós et d'Antônio Nobre à propos de la fin-de-siècle et du réalisme. L'histoire de la littérature considère le naturalisme une exagération du réalisme, malgré l'emploi des mêmes ressources rhétoriques comme: l'omniscience narrative dont $O$ crime do padre Amaro, O primo Basílio et Os Maias sont des exemples lapidaires; la description détaillée des romans d'Abel Botelho de la série de la Patologia social, du sèxe et de la pauvreté. Camilo Castelo Branco fait de confission réaliste en Eusébio Macário et A corja. La poésie de Cesário Verde et d'Antônio Nobre en font aussi, puisque chantent la vérité du travail, du travailleur, des classes populaires et de la misère sociale, que la prose n'a pas abbordée et qui a provoqué le rejet de leur oeuvre poétique. 